\title{
IMPLIKASI KEWENANGAN KECAMATAN DALAM PENYELENGGARAAN URUSAN PEMERINTAHAN UMUM (STUDI KASUS DI KECAMATAN PANDEGLANG KABUPATEN PANDEGLANG)
}

\author{
IMPLICATIONS OF DISTRICT AUTHORITY IN THE \\ OPERATION OF GENERAL GOVERNMENTAL AFFAIRS \\ (CASE STUDY IN PANDEGLANG DISTRICT PANDEGLANG \\ REGENCY)
}

\author{
Arif Nugroho \\ Program Studi Administrasi Negara, Universitas Serang Raya \\ Email : Ariyul88@gmail.com
}

\begin{abstract}
Abstrak
Penelitian ini membahas tentang implikasi kewenangan kecamatan dalam penyelenggaraan urusan pemerintahan umum. Pendekatan penelitian yang digunakan adalah deskriptif kualitatif. Teknik pengumpulan data menggunakan wawancara, dokumentasi dan telaah literatur dengan menggunakan teknik penentuan informan yaitu purposive sampling. Hasil penelitian menunjukan bahwa dalam penyelenggaraan pemerintahan umum kecamatan belum cukup tertopang oleh elemen necessary condition diantaranya kepastian atas kewenangan legalnya serta Anggaran. Maka dari pada itu perlu mendorong stakeholder kebijakan untuk menetapkan regulasi yang dapat memberikan optimalisasi pada implikasi kewenangan kecamatan dalam penyelenggaraan pemerintahan umum di Kecamatan Pandeglang Kabupaten Pandeglang.
\end{abstract}

Kata Kunci : Pemerintahan Umum, decentralization within cities, goverment

\begin{abstract}
This study discusses the implications of district authority in the administration of general government affairs. The research approach used is descriptive qualitative. Data collection techniques using interviews, documentation and study of literature using informant determination techniques namely purposive sampling. The results showed that in the administration of the general government of the sub-district was not sufficiently supported by elements of the necessary conditions including certainty over legal authority and the Budget. Therefore, it is necessary to encourage policy stakeholders to establish regulations that can provide optimization on the implications of the authority of the sub-district in the administration of general government in Pandeglang District, Pandeglang Regency.
\end{abstract}

Keywords: public administration, decentralization within cities, goverment

Pendahuluan 
Perjalanan otonomi daerah di Indonesia sudah berjalan selama 24 tahun. Selama kurun waktu tersebut sudah terdapat 542 daerah otonom hasil pemekaran yang terdiri dari 34 provinsi, 425 kabupatendan 93 kota. Meskipun demikian, implementasi otonomi daerah masih menghadapi berbagai permasalahan seperti lemahnya kapasitas personal, kelembagaan dan pembiayaan (Isnaeni, 2019). Oleh sebab itu fungsi supervisi, monitoring, kontrol dan pemberdayaan tetap menjadi tugas dan tanggung jawab pemerintah pusat agar otonomi daerah berjalan optimal, sebagaimana ditegaskan dalam Undang-undang No. 23/2014 yang telah diubah dengan Undang-undang nomor 9 tahun 2015 tentang pemerintah daerah yang menegaskan bahwa dalam penyelenggaraan otonomi daerah, tanggung jawab tertinggi dari penyelenggaraan pemerintahan tetap berada di tangan pemerintah pusat. Disisi lain kebijakan otonomi daerah telah mendorong adanya perubahan kedudukan pemerintahan daerah baik secara fungsional dan struktural bagi kecamatan yang sebelumnya merupakan perangkat wilayah dalam kerangka asas dekonsentrasi, berubah statusnya menjadi perangkat daerah dalam kerangka asas desentralisasi. Dengan demikian kecamatan dalam menjalankan tugasnya, mendapatkan pelimpahan kewenangan dari dan bertanggung jawab kepada bupati/walikota.

Kedudukan kecamatan sebagai bagian wilayah dari Kabupaten/Kota memiliki posisi yang relatif unik dikarenakan tidak memiliki urusan akan tetapi memiliki wilayah kerja. Meskipun demikian kecamatan yang dipimpin oleh seorang camat yang memiliki kecamatan sebagai bagian wilayah dari daerah kabupaten/kota tidak memiliki wewenang sebagai kepala wilayah pada umumnya.

Camat memiliki kewenangan dalam urusan umum di tingkat kecamatan yang merupakan tugas dari bupati/walikota yang dilimpahkan kepada camat sehingga kecamatan memiliki kewenangan atributif dalam hal penyelenggaraan urusan pemerintahan umum secara substantif bertujuan untuk penciptaan stabilitas wilayah guna terwujudnya penyelenggaraan pemerintahan di daerah yang dinamis. Dalam mendukung hal tersebut, Camat dibantu oleh Forum Koordinasi Pimpinan di kecamatan (Forkopimka) yang terdiri dari Kepala Kepolisian di Kecamatan, Kepala teritorial TNI di Kecamatan, dan instansi vertikal lain di Kecamatan dalam melakukan fungsi kontrol di wilayah melalui pembinaan, pengawasan dan pemberdayaan masyarakat dalam menjaga keamanan dan menciptakan ketertiban umum.

Secara hirarki kecamatan berada di bawah Pemerintah Kabupaten/kota dan memiliki kewenangan seperti melakukan pembinaan wawasan kebangsaan dan ketahanan nasional, persatuan dan kesatuan bangsa, pembinaan kerukunan masyarakat guna mewujudkan stabilitas keamanan, penanganan konflik sosial, dan pengembangan 
kehidupan demokrasi berdasarkan Pancasila. Dengan demikian kecamatan sebagai organisasi sektor publik di level pemerintahan daerah memiliki peran penting dan strategis.

Kecamatan Pandeglang Kabupaten Pandeglang merupakan salah satu kecamatan yang hingga saat ini melaksanakan fungsi-fungsi yang didasarkan pada konteks penyelenggaraan pemerintahan umum. Meskipun demikian dalam pelaksanannya, masih terdapat beberapa permasalahan seperti terbatasnya kapasitas sumberdaya manusia, belum adanya regulasi atau peraturan yang secara khusus tentang penyelenggaraan umum dan minimnya dukungan sumber dana.

Kecamatan sebagai garda terdepan pemerintah daerah dan berhadapan langsung dengan masyarakat mempunyai tugas membina desa/ kelurahan. Kecamatan merupakan sebuah organisasi yang hidup dan melayani kehidupan masyarakat. Sudut pandang kecamatan menurut (Norton, 1994) dapat dilihat dari berbagai wewenang dan urusan yang seharusnya diserahkan, terlihat mengikuti model decentralizations within city, terutama polanya dikatakan sebagai working towards a general pettern of decentralization of functions throughout the new area on the subsidiarity principle (bekerja mengarah pada pola umum fungsi desentralisasi melalui prinsip pembentukan cabang (subsidiarity) yang didasarkan pada area baru.

Menurut (Leemans, 1970) yang dikutip oleh (Maksum, 2014) bahwa terdapat dua model dari Field Administration yakni (1) Fragmented Field Administration yang terlahir dari Functional Based dimana membenarkan batas-batas wilayah kerja (yurisdiksi) dari perangkat departemen di lapangan secara berbeda menurut pertimbangan fungsi dan organisasi departemen induknya, (2) Integrated Field Administration yang terlahir dari Territorial Based dimana mengharuskan terdapatnya keseragaman batas-batas wilayah kerja (yurisdiksi) dari berbagai instansi vertikal atas Wilayah Administrasi beserta Wakil Pemerintah.

Kemudian menurut (Burns, Danny, 1994) kecamatan secara spesifik lebih mengarah pada bentuk decentralized management, atau bentuk decentralization yang bersifat deconcentration. Desentralisasi yang dekonsentrasi (delegasi) menciptakan Field Administration. Kebijakan desentralisasi secara substantif bertujuan menciptakan good governance yang meliputi pemerintah atau negara yang berdasarkan kepada hukum, transparansi, akuntabilitas, reabilitas informasi serta efisiensi dalam manajemen pemerintahan (Prasojo \& Kurniawan, 2008). Dengan demikian, kecamatan sebagai organisasi sektor publik yang melaksanakan fungsi penyelenggaraan pemerintahan umum berperan penting dalam menciptakan konstruksi hubungan secara vertikal dengan pemerintah daerah kabupaten/kota dan dengan kelurahan/desa. 
Adapun menurut Rondenelli, terdapat beberapa faktor yang memengaruhi proses implementasi desentralisasi, yaitu 1).Kuatnya dukungan politik dan administratif dari pemerintah pusat; 2). Pengaruh perilaku, tingkah laku dan budaya; 3).Faktor-faktor organisasi; 4)sumber daya keuangan dan fisik yang cukup memadai. Oleh sebab itu desentralisasi kewenangan pada kecamatan dapat dilakukan apabila faktor-faktor tersebut dapat dipenuhi.

Beberapa penelitian tentang kecamatan dalam berbagai multi perspektif sudah dilakukan, diantaranya oleh (Manurung et al., 2018) tentang implementasi kebijakan Pelayanan Administrasi Terpadu Kecamatan (PATEN) terhadap kualitas pelayanan publik di Kecamatan Sidikalang Kabupaten Dairi, dalam hasil penelitiannya dikemukakan bahwa sosialisasi yang dilakukan baik antara pihak Kabupaten dengan pihak Kecamatan belum sepenuhnya merata dan belum mampu meningkatkan kesadaran masyarakat, kualitas dan kuantitas aparatur yang belum memadai, koordinasi antar instansi terkait baik itu pihak yang kepentingannya dipengaruhi khususnya kecamatan. Sedangkan (Gunawan, 2014) dalam hasil penelitiannya mengatakan bahwa kewenangan yang telah diserahkan baik dari walikota dan bupati tidak sepenuhnya diserahkan, kelembagaan atau organisasi kecamatan belum menyesuaikan Peraturan Pemerintah Nomor 19 Tahun 2008, kualitas dan kuantitas sumber daya manusia menjadi hambatan dalam penyelenggaraan tugas-tugas atributif dan delegatif.

Penelitian tentang kecamatan mempunyai peran strategis dalam pelayanan publik dikemukakan oleh (Lodan, 2015) yan gmenyimpulkan kecamatan sebagai unit pemerintahan yang paling dekat dengan masyarakat belum menampakkan kontribusi yang maksimal karena hanya bersifat melaksanakan tugas-tugas administratif saja. Penguatan kelembagaan kecamatan akan sangat bergantung kepada kepala daerah (Bupati/Walikota) dalam melimpahkan kewenangannya sehingga dapat menjadi sebuah mekanisme pemberdayaan organisasi. Kemudian (Sagita, 2016) dalam hasil penelitiannya menyimpulkan bahwa bahwa pelaksanaan Tugas Pokok dan Fungsi Kasie Pemerintahan di Kecamatan dan Kelurahan Kota Bandung perlu adanya perbaikan untuk meningkatkan kinerja pelayanan.

Beberapa hasil penelitian tersebut menunjukkan peran penting dan strategis kecamatan dalam fungsi pelayanan, kewenangan dan kinerja pelayanan. Meskipun demikian penelitian tentang implikasi kewenangan kecamatan dalam penyelenggaraan pemerintahan umum belum dilakukan penelitian secara mendalam. Tujuan penelitian ini adalah menganalisis bagaimana implikasi kewenangan kecamatan dalam penyelenggaraan pemerintahan umum dengan studi kasus di Kecamatan Pandeglang Kabupaten Pandeglang. 


\section{Metode Penelitian}

Penelitian dilakukan dengan menggunakan pendekatan kualitatif. Teknik pengumpulan data yang dilakukan dalam penelitian ini yaitu wawancara, telaah dokumen dan literatur. Penentuan informan menggunakan teknik purpossive sampling. Teknik analisis data dalam penelitian ini menggunakan model analisis data interaktif dari (Miles et al., 2014). Penggambaran model analisis datanya dilakukan dengan langkah-langkah sebagai berikut:(1) Kondensasi data (data condensation); (2) Penyajian data (data display); (3) Penarikan kesimpulan (conclusions drawing).

\section{Pembahasan}

Undang-Undang Nomor 23 Tahun 2014 tentang Pemerintahan Daerah, mensyaratkan antara DAOT (Daerah Otonom) dengan WA (Wilayah Administrasi) sehingga seorang Kepala Daerah harus melakukan pengaturan kewenangan perangkatnya dalam penyelenggaraan Pemerintahan Daerah. Meskipun demikian pada hasil penelitian dapat dikemukakan adanya kontraproduktif terhadap pencapaian tujuan penyelengaraan pemerintahan umum, misalnya pada tahun 2015 lalu Pemerintah kabupaten lebak yang telah melarang berbagai aktifitas Organisasi Gerakan Fajar Nusantara (GAFATAR), namun pencekalan tersebut dikawatirkan oleh MUI (Majelis Ulama Indonesia) Pandeglang jika seluruh aktifitas organisasi tersebut berpindah ke pandeglang, alasannya karena letak yang berdekatan dan kultur yang tidak berbeda jauh (banten Hits, 16 Januari 2016).

Selanjutnya sebagaimana dikutip dari (detakbanten.com 24 Februari 2016) dengan berita yang berjudul antisipasi konflik sara, Bakesbangpol Pandeglang Gelar Rakor. Dalam isi berita tersebut bahwa pembentukan dan keberadaan Forum Pembaruan Kebangsaan (FPK), dibentuk untuk mengantisipasi terjadinya potensi konflik di dalam masyarakat yang disebabkan oleh masalah suku, agama dan ras. FPK telah dibentuk di 8 (delapan) kecamatan di kabupaten pandeglang yakni di kecamatan Pandeglang, Majasari, Karangtanjung, Cadasari, Labuan, Paninmbang, Cikeusik, Sumur. Langkah awal yang akan dilakkukan oleh FPK adalah melakukan pembinaan secara konsiten pada 51 orang ex anggota GAFATAR yang telah dipulangkan ke kampung halamannya di Pandeglang.

Beberapa kondisi hal di atas menunjukkan adanya kondisi empiris yang terjadi beserta kopleksitasnya sehingga membawa pada tantangan dan ancaman atas tercapainya tujuan dari penyelengaraan pemerintahan umum. tersebut yang diamanatkan dalam Undang-Undang Nomor 23 Tahun 2014. Oleh sebab itu kecamatan sebagai perangkat wilayah administrasi difokuskan pada kewenangan Ketentraman dan ketertiban umum serta kesatuan bangsa. Sejauh ini dalam pengaturan kewenangan camat/ kecamatan hal - 
hal tersebut sudah diselenggarakan dalam kapasitas kewenangan perangkat daerah. Dalam hal ini kecamatan berkedudukan ganda sebagai perangkat wilayah administrasi penyelenggara pemerintahan umum dan sebagai perangkat daerah otonom. Konsekuensi dari itu, secara konseptual camat/kecamatan dituntut mampu menjadi daya dukung pencapaian tujuan penyelanggaraan pemerintahan daerah dari 32 urusan otonomi daerah dan juga tujuan penyelenggaraan pemerintahan umum. Adapun anatomi urusan pemerintahan Undang - Undang Nomor 23 Tahun 2014 digambarkan sebagai berikut ;

Gambar 2 Anatomi Urusan Pemerintahan.

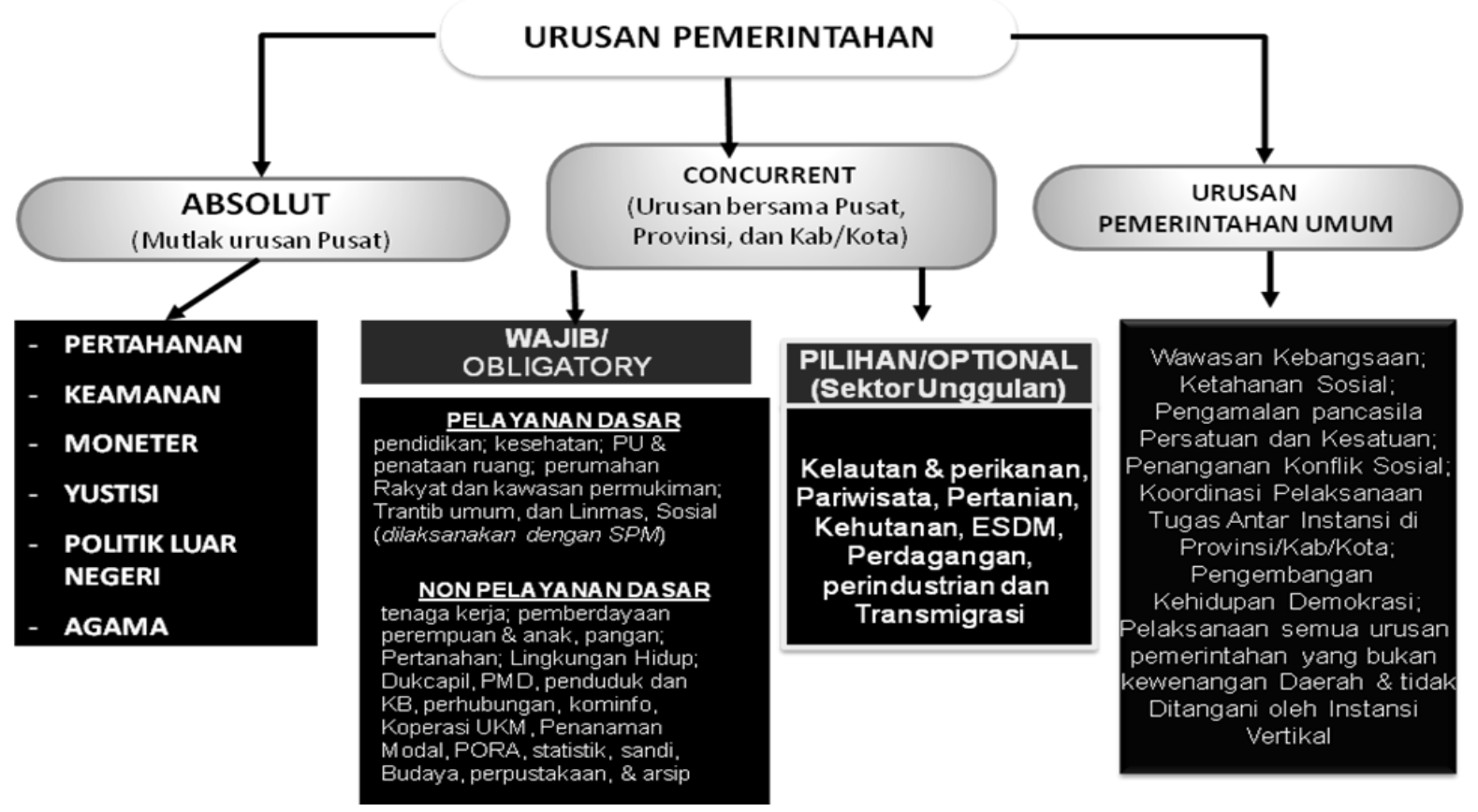

Sumber : Paparan Direktur Dekonsentrasi, Tugas Pembantuan

Dan Kerjasama (2016)

Penyelenggaraan pemerintahan umum sudah berjalan secara efektif (Instansi Vertikal Direktorat Jendral Politik dan Pemerintahan Umum sudah ada di kabupaten/kota), satu satunya mitra yang strategis dalam bidang kesatuan bangsa yang 
paling strategis adalah Kecamatan. Hal itu karena kecamatan adalah perangkat kewilayahan. Sharing informasi dengan kecamatan - kecamatan yang lain pun relatif mudah dengan format kesatuan bangsa, dibandingkan dengan pihak TNI dan Polri yang cenderung informasinya dengan format pertahanan dan keamanan. Hal ini menunjukkan sudah terdapat sinergis antara berbagai stakeholder kebijakan dalam melaksanakan fungsifungsi penyelenggaraan pemerintahan umum serta berimplikasi pada kondisi dinamis masyarakat kecamatan Pandeglang yang terus mengalami perkembangan.

Kondisi eksisting penyelenggaraan pemerintahan umum di kabupaten/ kota dijelaskan pada gambar sebagai berikut :

\section{Gambar .3 Kondisi Eksisting Kebijakan Penyelenggaraan}

Pemerintahan Umum.

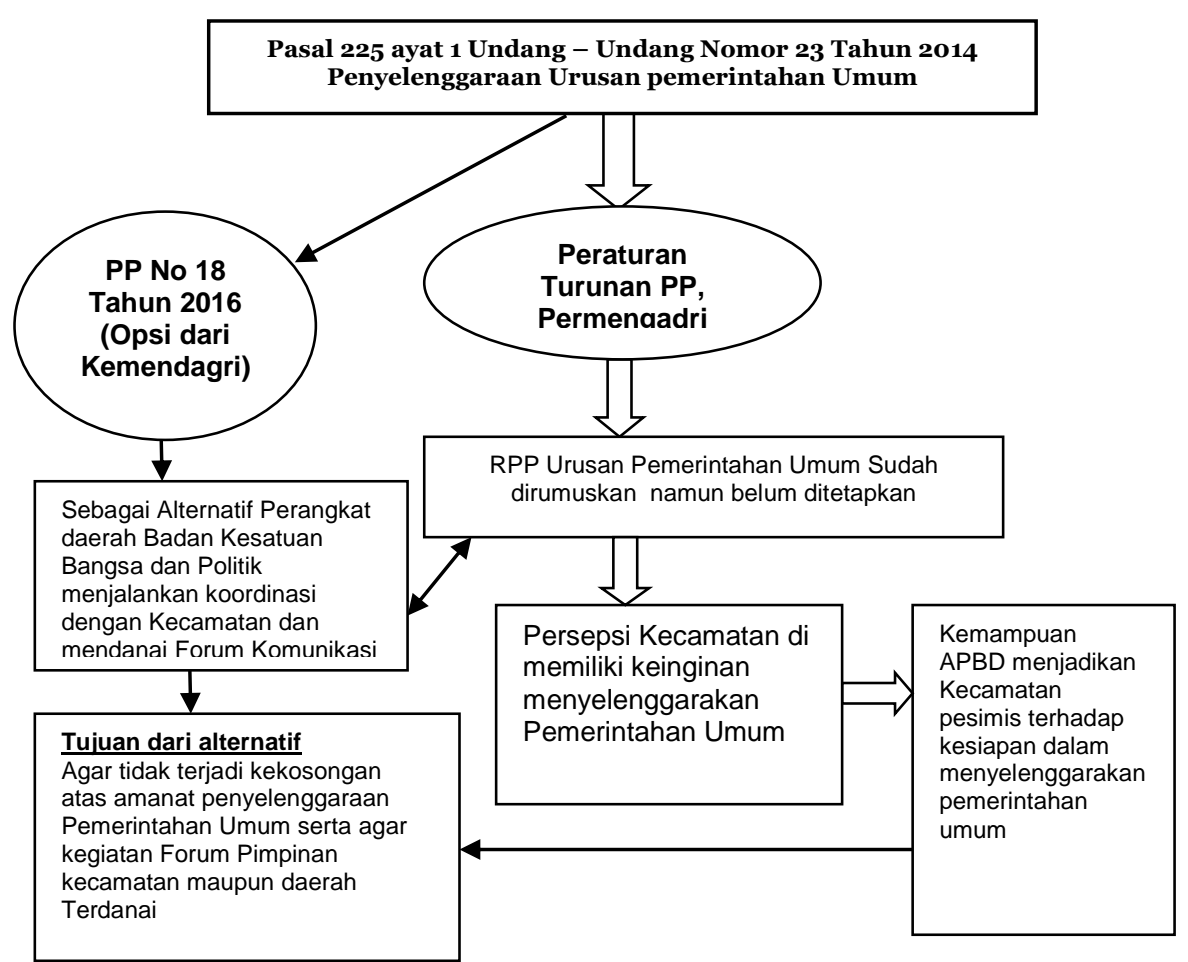

Sumber Data Diolah Peneliti 2019 
Terkait dengan gambar di atas, seiring dengan diterapkanya Undang-Undang Nomor 23 Tahun 2014 dan penegasan pada Peraturan Pemerintah Nomor 17 Tahun 2018 terjadi perubahan fungsi dan kedudukan Kecamatan, hal tersebut dapat dilihat dari arah kebijakan yang dirumuskan dalam RPP (Rancangan Peraturan Pemerintah) penyelenggaraan pemerintahan umum bahwa kecamatan secara operasional kedudukannya membantu Pemerintah Kabupaten dan instansi vertikal Direktorat Jenderal Politik dan Pemerintah Umum Kementerian Dalam Negeri Kabupaten dalam penyelenggaraan pemerintahan umum, Camat secara atributif menjadi Pimpinan Forkopimka (Forum Koordinasi Pimpinan Kecamatan), kedudukan tersebut berjenjang dari tingkat Pusat, Provinsi hingga kabupaten/kota. Dalam hal ini Camat kembali memiliki kewenangan secara atributif sebagai Forum Pimpinan di tingkat kecamatan. Konsekuensi kedudukan Kecamatan sebagai perangkat wilayah administrasi penyelenggara urusan pemerintahan umum sesuai dengan Pasal 225 ayat (2) akan memperoleh Pendanaan dari sumber APBN dan pelaksanaan tugas lain dibebankan kepada yang menugasi (Presiden Sebagai Kepala Pemerintahan).

Selanjutnya dapat dikemukakan, keberadaan RPP penyelenggaraan pemerintahan umum yang hingga saat ini belum disahkan oleh presiden sehingga memunculkan konsekuensi pada ketidakpastian mekanisme penyelenggaraan serta dukungan pendanaan yang bersumber dari APBN (Anggaran Pendapatan dan Belanja Negara). Disisi lain, pemerintah kabupaten/kota memiliki kemauan dan keinginan mengimplementasikan penyelenggaraan pemerintahan umum, akan tetapi yang menjadi permasalahan adalah masih terbatasnya kemampuan dan kesiapan kecamatan. Dalam pagu indikatif pada kecamatan selama ini tergolong minim, misalnya sebagai contoh di Kabupaten Pandeglang yakni Rp 710.757.600.,00 pada tahun 2017 dan menurut informasi di daerah lain 500 juta bahkan ada yang dibawah 500 juta di tahun - tahun sebelumnya. Selain itu keterbatasan Sumberdaya manusia menjadi faktor penghambat efektifitas penyelenggaraan pemerintahan umum, dalam hal ini alokasi anggaran khusus dari Pemerintah Pusat harus menjadi kebijakan prioritas.

Terkait dengan perkembangan RPP (Rancangan Peraturan Pemerintah) penyelenggaraan pemerintahan umum, diketahui hingga saat ini RPP terkait vertikalisasi Kesbangpol dan penyelenggaraan urusan pemerintahan umum sudah diajukan pada Presiden, namun belum ditanda tangani. Karena ada pertimbangan kemampuan APBN yang diestimasi akan tersedot hingga 10 Triliun ketika PP (Peraturan Pemerintah) tersebut diterapkan. Namun dari Kemendagri menyatakan Peraturan Pemerintahnya belum turun sampai waktu yang belum bisa ditentukan dan menyarankan alternatif membiayai kegiatan 
Forkopimda (Forum Koordinasi Pimpinan Daerah) dan Forkopimka (Forum Koordinasi Pimpinan Kecamatan) sementara dengan APBD. Jadi Alternatif pembiayaan dari sumber APBD adalah sebuah pilihan yang sifatnya kondisional yang didasarkan pada kemampuan APBD yang dimiliki, termasuk bagi Pemerintah kabupaten pandeglang.

Kondisi demkian menyebabkan implikasi terhadap pembangunan daerah di Kecamatan. Desentralisasi akan menciptakan peluang-peluang yang lebih besar bagi inovasi dan eksperimen, serta bagi proses pembelajaran dan proses difusi dari eksperimen kebijakan yang baik. Hal tersebut akan memudahkan terciptanya aktivitas pemerintahan yang lebih efektif karena adanya struktur koordinasi di daerah (Rondinelli et al., 1983). Camat secara atributif menjadi Pimpinan Forkopimka (Forum Koordinasi Pimpinan Kecamatan), kedudukan tersebut berjenjang dari tingkat Pusat, Provinsi hingga kabupaten/kota. (Meir, Ben, 2010) mengatakan bahwa Deconcentration transfers central government authority to lower levels within ministries. However, deconcentration also includes enabling provincial and district level bureaucracies to work closely with other sub-national groups within a democratic framework. Kecamatan sebagai perangkat wilayah administrasi penyelenggara urusan pemerintahan umum sesuai dengan Pasal 225 ayat (2) akan memperoleh Pendanaan dari sumber APBN.

Implikasi penyelenggaraan pemerintahan yang kurang optimal yang disebabkan kebijakan dari Pemerintah pusat, sehingga memberikan advice kepada daerah untuk mensiasati pendanaan dari APBD dalam pendanaan Forkopim baik di tingkat Kabupaten/kota maupun kecamatan. (Muluk, 2009) mengatakan bahwa dalam hal ini konsep otonomi daerah merupakan wewenang untuk mengatur urusan pemerintahan yang bersifat lokalitas menurut prakarsa sendiri berdasarkan aspirasi masyarakat setempat, dengan begitu baik masyarakat dan birokrasi penyelengaraan pemerintahan daerah setempat untuk dapat memecahkan berbagai masalah dan pemberian layanan yang bersifat lokalitas demi kesejahteraan masyarakat yang bersangkutan. Faktanya beberapa daerah salah satunya yakni kabupaten Pandeglang memiliki dalih keterbatasan kemampuan APBD. Jika APBD yang jadi masalah, langkah terbaik yang tetap harus dilakukan dalam rangka melaksanakan amanat Undang - Undang atau minimalnya esensi yang menjadi tujuanya, kecamatan bisa saja melakukan siasat - siasat. (Rondinelli, 1983) dikutip oleh (Pitono, 2012) bahwa field administration, pejabat lapangan diberi keleluasaan untuk mengambil keputusan seperti merencanakan, membuat keputusan-keputusan rutin, dan menyesuaikan pelaksanaan kebijakan pusat dengan kondisi setempat. Hasil penelitian menunjukan tidak sedikit terjadi permasalahan sosial kemasyarakatan terjadi, yang mana itu domain dari kewenangan penyelenggaraan pemerintahan umum kecamatan. Intinya dengan kondisi yang seperti itu 
camat sedang dituntut kreatifitasnya bagaimana caranya dengan keterbatasan sumber daya yang ada namun mampu menangani semaksimal mungkin.

\section{Penutup}

Mengingat landasan operasional berupa Peraturan Pemerintahan belum ditetapkan yang terkait dengan operasionalisasi dan kepastian dukungan APBN, maka pendanaan penyelenggaraan pemerintahan umum dilakukan dengan APBD. Meskipun terdapat keterbatasan kemampuan APBD. Dengan demikian inovasi dalam rangka menjalankan amanat penyelenggaraan pemerintah umum, seperti pembagian kewenangan dan alokasi anggaran Bakespangpol untuk kecamatan. Disisi lain, mendorong komitmen dari kepala daerah, dalam melakukan terobosan agar dapat mengantisipasi permasalahan-permasalahan yang terjadi dalam penyelenggaraan pemerintahan umum di kecamatan.

\section{Referensi}

Burns, Danny, E. al. (1994). The Politic of Decentralization, Revitalising Local Democracy. Hongkong: MacMillan.

Gunawan. (2014). Peran dan Fungsi Kecamatan dalam Penyelenggaraan Pemerintahan Daerah di Kota Semarang dan Kabupaten Semarang Jawa Tengah. Bina Praja, 6(4), 315-328. https://doi.org/10.21787/jbp.06.2014.315-328

Isnaeni, H. F. (2019, September). Menelaah Sejarah Otonomi Daerah. Historia. https:// historia.id/politik/articles/menelaah-sejarah-otonomi-daerah-Dwg2Z

Lodan, K. T. (2015). Peran Strategis Kecamatan Dalam Pelayanan Publik ( Studi di Kecamatan Sagulung Kota Batam )”. Sosial Dan Humaniora Kopertis X, 1, 1-11.

Maksum, I. R. (2014). Pemerintahan Umum Berbasis Dekonsentrasi Jurnal Ilmu Pemerintahan Edisi 44 Tahun 2014. Jurnal Ilmu Pemerintahan, 44.

Manurung, A. S., Kusmanto, H., \& Tarigan, U. (2018). Implementasi Kebijakan Pelayanan Administrasi Terpadu Di Kecamatan Natar Lampung Selatan. Administrasi Publik,6(1),47-57.https:// doi.org/10.1017/CBO9781107415324.004

Meir, Ben, Y. (2010). "Morocco's Regionalization 'Roadmap' and the Western Sahara". Ifrane: Al Akhawayn University,. Journal On World Peace, XXVII(2).

Miles, M. B., Huberman, M. A., \& Saldaña, J. (2014). Qualitative Data Analysis A Methods Sourcebook. In Qualitative Data Analysis A Methods Sourcebook (3rd ed.). 
SAGE Publications Inc.

Muluk, M. R. K. (2009). Peta Konsep Desentralisasi dan Pemerintahan Daerah. Surabaya: ITS Press.

Norton, A. (1994). International Handbook of Local and Regional Government, A Comparative Analysis of Advenced Democracies. Adaward Egar, UK.

Pitono, A. (2012). Asas Dekonsentrasi dan Asas Tugas Pembantuan dalam Penyelenggaraan Pemerintahan. Jurnal Kebijakan Publik, Volume 3(1), hlm. 1-55.

Prasojo, E., \& Kurniawan, T. (2008). Reformasi Birokrasi dan Good Governance: Kasus Best Practices dari Sejumlah Daerah di Indonesia. The 5 Th International Symposium of Jurnal Antropologi Indonesia, Banjarmasin. 22-25 Juli 2008, 1-15.

Rondinelli, D. A., Nellis, J. R., \& Cheema, G. S. (1983). Decentralization in Developing Countries (A Review of Recent Experience) (Issue 581). The World Bank.

Sagita, N. I. (2016). Pelaksanaan Peran dan Fungsi Kepala Seksi Pemerintahan di KecamatandanKelurahanKotaBandung.Agregasi,4(2).https://doi.org/10.1017/CBO9 781107415324.004 
Spirit Publik Volume 15, Nomor 1, 2020

Halaman 60-70

P-ISSN. 1907-0489 E-ISSN 2580-3875 